\title{
Cyclin-Dependent Kinase 5 Is Required for Associative Learning
}

\author{
André Fischer, Farahnaz Sananbenesi, Christina Schrick, Joachim Spiess, and Jelena Radulovic \\ Department of Molecular Neuroendocrinology, Max Planck Institute for Experimental Medicine, \\ 37075 Goettingen, Germany
}

\begin{abstract}
Transient stressful experiences may persistently facilitate associative and nonassociative learning, possibly through alterations of gene expression. Here we identify, by subtractive hybridization, differential expression of the Cdk5 gene in response to stress. The Cdk5 protein is selectively induced in the fibers of septohippocampal cholinergic neurons but not in other regions of prominent Cdk5 production. This upregulation is accompanied by increased Cdk5 kinase activity, which is blocked completely by the Cdk5 inhibitor butyrolactone I. Mi-
\end{abstract}

croinjection of butyrolactone I into the lateral septum and hippocampus prevents the acquisition of conditioned contextdependent fear as well as its stress-induced facilitation. By demonstrating that a transient increase of Cdk5 activity within the septohippocampal system is required for associative learning, an important novel role of Cdk5 has been identified.

Key words: cyclin-dependent kinase 5; stress; fear conditioning; septum; hippocampus; cholinergic; mice
Memory formation requires a series of molecular processes, such as protein phosphorylation, gene expression, and de novo protein synthesis, leading to functional and structural changes of neuronal cells (Silva et al., 1997; Abel et al., 1998). Consolidation of memory is markedly enhanced by defined acute stressful experiences (Shors et al., 1992; Radulovic et al., 1999), indicating that molecular cascades elicited by stress responses interfere with those involved in information processing during learning (Silva et al., 1997; Serova et al., 1998). Notably, stress and learning may activate overlapping signaling pathways involving common protein kinases, immediate early genes, and delay-response genes (Cammarota et al., 2000). Therefore, the understanding of stressinduced molecular changes in the brain could lead to the elucidation of mechanisms underlying learning and memory.

Context-dependent fear conditioning is a rapidly acquired form of associative learning with a defined time window of memory consolidation. Therefore, it has been commonly used to study the brain regions, neuronal circuits, and molecular changes involved in associative learning. Context-dependent fear conditioning requires the coordinated activity of forebrain limbic structures involving, among others, the septohippocampal region (Maren and Fanselow, 1997). This brain area is also involved in long-lasting facilitation of fear conditioning by stress (Mark et al., 1996; Radulovic et al., 1999). We have previously demonstrated stress-enhanced fear conditioning in mice trained for $3 \mathrm{hr}$ but not immediately after the end of acute immobilization, serving as a stressful stimulus (Radulovic et al., 1999). The same procedure did not result in contextual generalization or nonspecific increases of freezing (Radulovic et al., 1999). On the basis of the

\footnotetext{
Received Dec. 10, 2001; revised Jan. 25, 2002; accepted Jan. 29, 2002.

This research was supported by the Max Planck Society. We thank C. Todorovic and M. Radulovic for comments, B. Hesse-Niessen for sequencing, and A. Burgdorf and J. Ficner for assistance with the preparation of this manuscript.

Correspondence should be addressed to André Fischer, Max Planck Institute for Experimental Medicine, Department for Molecular Neuroendocrinology, Hermann-Rein-Strasse, 37075 Goettingen, Germany. E-mail: fischer@mail.em. mpg.de.

Copyright (C) 2002 Society for Neuroscience $\quad 0270-6474 / 02 / 223700-08 \$ 15.00 / 0$
}

observed time course, we hypothesized that the effects of stress on learning might be mediated through alterations of septohippocampal gene expression.

To identify differentially expressed genes in response to stress, we compared hippocampal and septal mRNA of stressed mice with corresponding mRNA of control mice using subtractive hybridization. By this approach, $C d k 5$ was identified as a differentially expressed gene in the septum of stressed mice. The Cdk5 protein was selectively upregulated in septohippocampal neurons, as revealed by its colocalization with acetylcholinesterase and neurofilament 68. Cdk5 obtained from septohippocampal lysates of stressed mice was associated with its activator p35 and exhibited increased kinase activity. Regional microinjections of the Cdk5 inhibitor butyrolactone I into the septum or hippocampus profoundly impaired associative learning as well as its stressinduced facilitation.

Taking into account that so far, $\mathrm{Cdk} 5$ has been linked primarily to processes of cell differentiation and axonal growth, the demonstrated patterns of $\mathrm{Cdk} 5$ induction, localization, and function within the septohippocampal cholinergic system unravel the involvement of novel molecular cascades and processes underlying learning and memory.

\section{MATERIALS AND METHODS}

Subjects. Eight-week-old male BALB/c mice (Charles River Laboratories, Sultzfeld, Germany) were individually housed as described previously (Radulovic et al., 1999). Experiments were performed in accordance with the European Council Directive (86/609/EEC). The number of mice per group was 20 for mRNA preparations, 3-5 for protein production studies and kinase assays, and 8-12 for behavioral experiments.

Immobilization. Immobilization of mice consisted of taping their limbs to a Plexiglas surface for $1 \mathrm{hr}$ (Radulovic et al., 1999). Control mice were left in their home cages and exposed to the same context without immobilization.

Cannulation and injections. Cannulation into the lateral brain ventricles, the lateral septum, and the hippocampus was performed as described previously (Radulovic et al., 1999). The Cdk5 inhibitor butyrolactone I [10 $\mu \mathrm{M}$ in $0.2 \%$ DMSO in artificial CSF (aCSF)] was injected $(0.25 \mu \mathrm{l} / \mathrm{side}) 15 \mathrm{~min}$ before training or immobilization. Vehicle was 
$0.2 \%$ DMSO in aCSF. In some experiments, the same dose of butyrolactone I was injected immediately or $3 \mathrm{hr}$ after the training, as indicated. Only data obtained from mice with correctly inserted cannulas, as verified after methylene blue injection, were included in statistical analysis.

Context-dependent fear conditioning. Training consisted of a $3 \mathrm{~min}$ exposure of mice to the conditioning box (context) followed by a foot shock (2 sec, $0.7 \mathrm{~mA}$, constant current) (Milanovic et al., 1998). The memory test was performed $24 \mathrm{hr}$ later by re-exposing the mice for $3 \mathrm{~min}$ into the conditioning context. Freezing, defined as a lack of movement except for heart rate and respiration associated with a crouching posture, was recorded every $10 \mathrm{sec}$ by two trained observers (one was unaware of the experimental conditions) during $3 \mathrm{~min}$ (a total of 18 sampling intervals). The number of observations indicating freezing obtained as a mean from both observers was expressed as a percentage of the total number of observations. Control groups of mice were exposed to the context alone $(3 \mathrm{~min})$ or immediate foot shock $(2 \mathrm{sec}, 0.7 \mathrm{~mA}$, constant current) followed by context $(3 \mathrm{~min})$ during the training.

Tone-dependent fear conditioning. Training consisted of a $3 \mathrm{~min}$ exposure of mice to the conditioning box (context), followed by a tone [30 sec, $10 \mathrm{kHz}, 75 \mathrm{~dB}$ sound pressure level (SPL)] and a foot shock (2 sec, 0.7 $\mathrm{mA}$, constant current) (Radulovic et al., 1999). The memory test was performed $24 \mathrm{hr}$ later by exposing the mice for $3 \mathrm{~min}$ into a novel context followed by an additional $3 \mathrm{~min}$ exposure to a tone (10 kHz, $75 \mathrm{~dB}$ SPL). Freezing was recorded every $10 \mathrm{sec}$ by two nonbiased observers as described above.

Isolation of $m R N A$ and subtractive hybridization. The septum from immobilized and control mice was removed (60 mg tissue/group). The isolation of mRNA was performed according to the $\mu$ Macs mRNA Isolation Kit (Milteny Biotec, Bergisch-Gladbach, Germany), followed by DNase treatment and precipitation with ice-cold absolute ethanol. cDNA was synthesized according to the SMART cDNA Synthesis Kit (Clontech, Cambridge, UK). Subtractive hybridization was performed according to the user's manual of the Clontech PCR-Select cDNA Subtraction Kit using septal cDNA obtained from immobilized mice as tester probes and cDNA of control mice as driver probes with a testerto-driver ratio of 1:100. A differentially expressed $312 \mathrm{bp}$ fragment was identical to mouse $C d k 5$ described in the GenBank database (Basic Logical Alignment Search Tool fileserver).

Semiquantitative reverse transcription-PCR. cDNA obtained as described above was used as a template for PCR with the following thermocycle: $30 \mathrm{sec}$ at $94^{\circ} \mathrm{C}, 30 \mathrm{sec}$ at $65^{\circ} \mathrm{C}$, and $60 \mathrm{sec}$ at $72^{\circ} \mathrm{C}$. The antisense primer $5^{\prime}$-ACATCATTGCCAGGGAAGAGAGGTC-3' and sense primer 5'-GATGACGATGAGGGTGTGCCAAGTT-3' were used to obtain a $534 \mathrm{bp}$ fragment of the cDNA sequence of the mouse $C d k 5$ gene. As an internal control for the quality of reverse-transcribed samples, a $766 \mathrm{bp}$ fragment of mouse $\beta$-actin cDNA was amplified using 5'-AAGATGACCCAGATCATGTTTGAGAC-3' as a sense primer and 5'-CTGCTTGCTGATCCACATCTGCTGG-3' as an antisense primer. Samples were analyzed on a $1.8 \%$ agarose gel containing ethidium bromide, and their intensity was densiometrically quantified (WinCam 2.2, Cybertech, Berlin, Germany).

In situ hybridization. Microtome sections of $20 \mu \mathrm{m}$ thickness were fixed with $4 \%$ paraformaldehyde, followed by washing with PBS. The sections were then incubated for $5 \mathrm{~min}$ with $0.1 \mathrm{M}$ triethanolamine (TEA), followed by incubation with $0.1 \mathrm{M}$ TEA containing $0.5 \%$ acetic anhydride. Prehybridization was performed by incubating the sections in hybridization buffer [50\% formamide, $2 \%$ blocking agent (Boehringer Mannheim, Mannheim, Germany), $0.02 \%$ SDS, $0.1 \%$ sarcosyl $/ 1 \times$ SSC] for $4 \mathrm{hr}$, followed by hybridization with a digoxigenin-labeled probe diluted in hybridization buffer for $16 \mathrm{hr}$ at $48^{\circ} \mathrm{C}$. After hybridization, the sections were incubated with RNaseA $(10 \mu \mathrm{g} / \mathrm{ml})$ and washed with $2 \times$ SSC and $0.2 \times$ SSC. After washing, the specimens were first incubated with $1 \%$ blocking agent $/ 0.1 \mathrm{M}$ maleic acid, followed by an alkaline phosphatase-conjugated anti-digoxigenin antibody (Boehringer Mann-
A

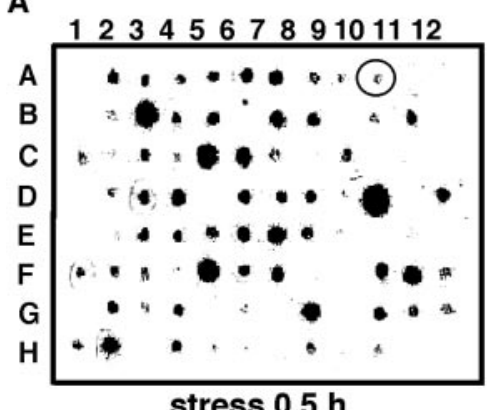

stress $0.5 \mathrm{~h}$

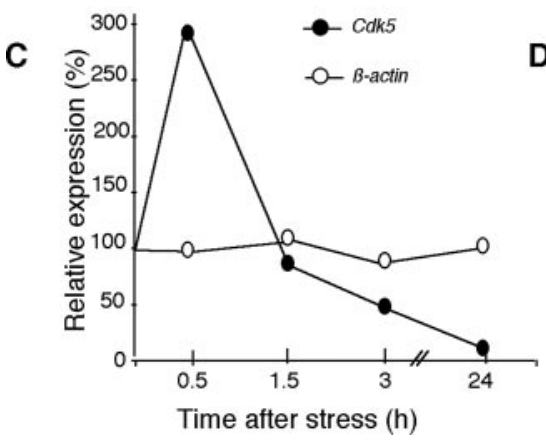

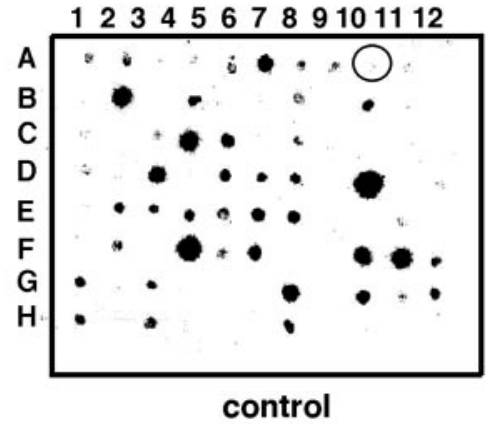

D

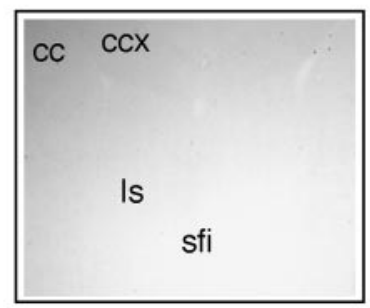

sense

B
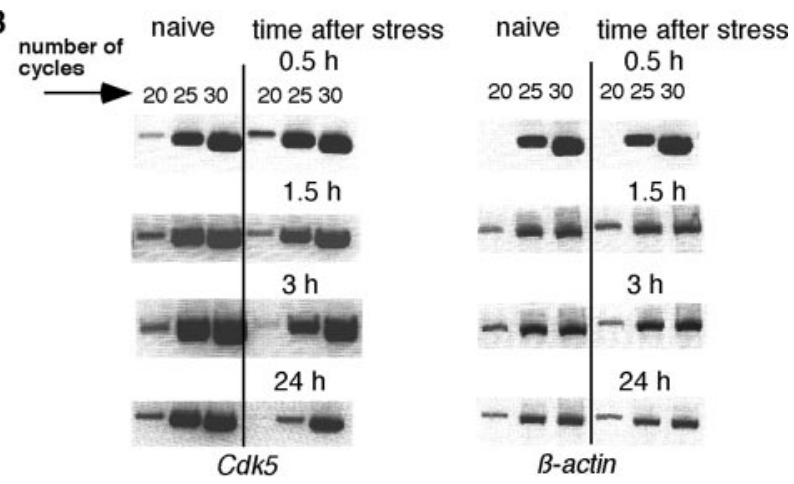

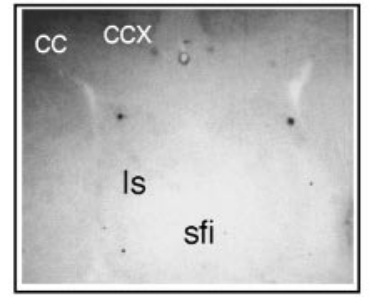

anti-sense/naive

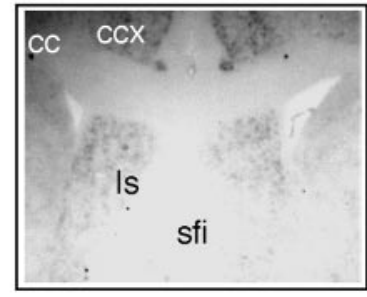

anti-sense/stress $0.5 \mathrm{~h}$

Figure 1. Upregulation of $C d k 5$ gene expression in response to acute immobilization. $A$, Differential screening of clones obtained after subtractive hybridization of septal cDNA. The $C d k 5$ fragment is marked with a circle. $B$, Representative RT-PCRs showing amplification of $C d k 5$ and $\beta$-actin $\mathrm{cDNA}$ fragments after 20,25, and 30 cycles. Septal cDNA obtained at indicated time points after immobilization or from naive mice was used as a template. The Cdk5 signal was increased 30 min after the end of immobilization after 20 cycles of amplification. $C$, The RT-PCR signals for Cdk5 and $\beta$-actin obtained after 20 cycles of amplification were quantified densitometrically. A histogram from a representative measurement is presented. The data were obtained from RT-PCR performed in parallel for $C d k 5$ and $\beta$-actin for each time point. The results were replicated in three independent experiments. The values obtained for stressed mice were normalized against the values of naive mice. $D$, Representative in situ hybridization showing $C d k 5$ mRNA expression in the lateral septum of naive mice and mice stressed for $1 \mathrm{hr}$ and killed $0.5 \mathrm{hr}$ later. $c c$, Corpus callosum; $c c x$, cingulate cortex; $s f$, septofimbrial nucleus; $l s$, lateral septum. 
Figure 2. Upregulation of $\mathrm{Cdk} 5$ protein production in the septum and hippocampus of mice stressed for $1 \mathrm{hr}$ and killed $0.5 \mathrm{hr}$ later. $A, \mathrm{Cdk} 5$ protein levels in the septum at different time points after the end of immobilization. Left, Densitometric quantification of the immunostaining for $\mathrm{Cdk} 5$. The number of mice per group was three to five. Right, Representative immunostaining of the lateral septum. Scale bar, $200 \mu \mathrm{m}$. $B, \mathrm{Cdk} 5$ protein levels in the hippocampus at different time points after the end of immobilization. Left, Densitometric quantification of the immunostaining for Cdk5. The number of mice per group was three to five. Right, Representative immunostaining of the hippocampus. Arrows indicate main areas of $\mathrm{Cdk} 5$ production. Scale bar, $400 \mu \mathrm{m}$. Statistically significant differences: ${ }^{*} p<$ $0.05,{ }^{* * *} p<0.001$ versus naive mice. CA1, Hippocampal subfield; $D 3 \mathrm{~V}$, dorsal third ventricle; $D G$, dentate gyrus; $L S I$, lateral intermediate septum; $M S$, medial septum; $o$, stratum oriens; $r$, stratum radiatum.
A

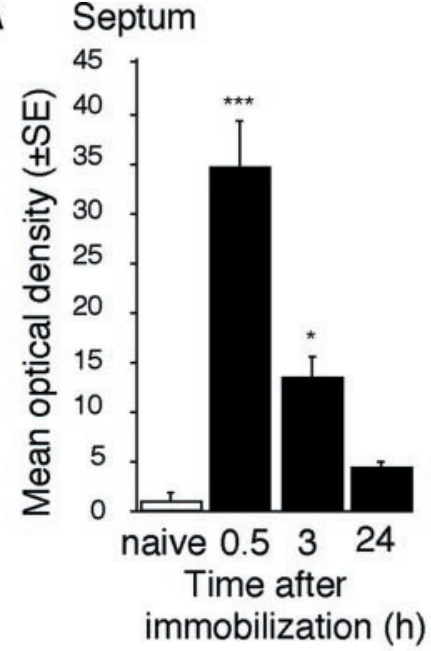

B Hippocampus

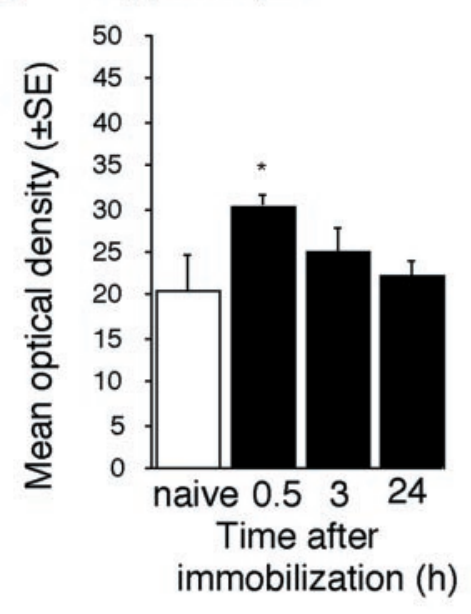



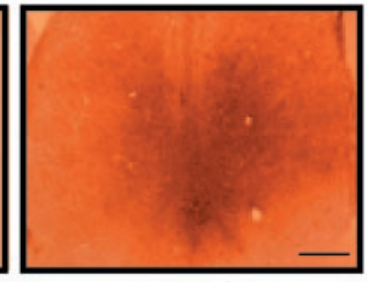

naive



$3 \mathrm{~h}$

$0.5 \mathrm{~h}$

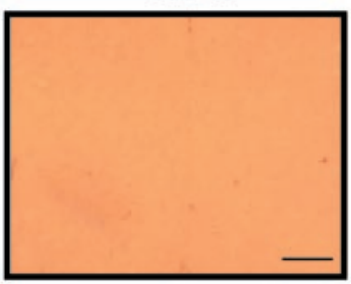

$24 \mathrm{~h}$

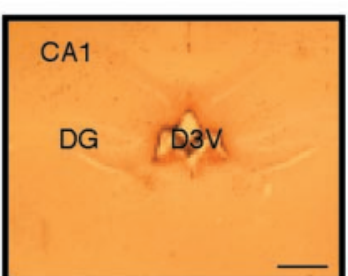

naive



$3 \mathrm{~h}$

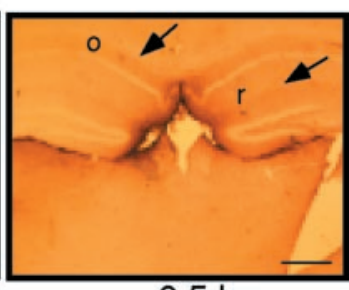

$0.5 \mathrm{~h}$

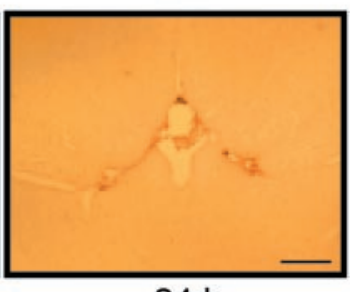

$24 \mathrm{~h}$ heim) diluted 1:2000 in $1 \%$ blocking agent/0.1 M maleic acid for $1 \mathrm{hr}$. Sections were washed several times and developed by the addition of 5-bromo-4-chloro-3-indolyl-phosphate/nitroblue tetrazolium. The $534 \mathrm{bp}$ fragment of the cDNA sequence of mouse $C d k 5$ gene obtained by reverse transcription (RT)-PCR (see above) was reverse-transcribed to obtain sense and antisense probes. These probes were adjusted to an average length of 200 bp by limited alkaline hydrolysis.

Chemicals and antibodies. Butyrolactone I was purchased from Biomol (Plymouth Meeting, PA); antibodies for Cdk5 (J-3), p35 (N-20, H-72, and C-19), acetylcholine esterase (E-19), and Cdk2 (H-298) were obtained from Santa Cruz Biotechnology (Santa Cruz, CA); Cdk1/Cdc2 (06-141) was purchased from Biomol; and neurofilament 68 was supplied by Sigma (St. Louis, MO). The dilutions of antibodies used for immunohistochemical and immunoblot analysis were 1:1000 for Cdk5, p35, $\mathrm{Cdk} 1 / \mathrm{Cdc} 2$, and $\mathrm{Cdk} 2$ and 1:400 for neurofilament 68 and acetylcholinesterase. For coimmunolabeling studies, the anti-Cdk5 antibody was diluted 1:500.

Immunohistochemical analysis. Immunohistochemical analysis was performed and quantified as described previously (Radulovic et al., 1998a; Kishimoto et al., 2000). Briefly, the total area of the septum of each mouse was outlined at the anatomic coordinates +0.4 to $+0.6 \mathrm{~mm}$ anterior to the bregma (Franklin and Paxinos, 1997). The same threshold was applied for each section, and the density of staining was determined automatically with a Macintosh-based imaging system (NIH Image; National Institutes of Health, Bethesda, MD). The mean gray values obtained at the level of the corpus callosum, indicating background staining, were subtracted from the total density. For coimmunolabeling studies, the Tyramide Signal Amplification Fluorescence System (NEN Life Science Products, Boston, MA) was used, with tetramethylrhodamine and fluorescein as substrates. The sections were first stained with the avidin-biotin complex system (Vector Laboratories, Burlingame, CA) and subsequently with an antibody directly labeled with peroxidase (Sigma). Multicolor immunofluorescence was observed with a triplebandpass filter (Appligene, Heidelberg, Germany).

Protein extraction and immunoblot. The septum and hippocampus were collected and lysed in radioimmunoprecipitation buffer (Nikolic et al., 1998). The lysates were incubated for $15 \mathrm{~min}$ on ice and centrifuged for $15 \mathrm{~min}$ at $15,000 \times \mathrm{g}$ and $4^{\circ} \mathrm{C}$. The supernatant was collected as cytosolic protein extract. The lysates were subjected to $12.5 \%$ SDS-PAGE followed by immunoblotting as described previously (Radulovic et al., 1998a).

Immunoprecipitation and kinase assay. For immunoprecipitation, 0.5 $\mu \mathrm{g}$ of total protein was incubated for $1 \mathrm{hr}$ at $4^{\circ} \mathrm{C}$ with $2 \mu \mathrm{g}$ of anti-cdk5 or anti-p35 antibody, followed by incubation for $30 \mathrm{~min}$ on ice with magnetically labeled protein $\mathrm{G}$ or A microbeads. Washing and elution were performed as described in the MAGmol Microbeads user's manual (Milteny Biotec).

For kinase assay, the complexes were not eluted but instead incubated twice with $25 \mu \mathrm{l}$ of reaction buffer containing kinase buffer (Sharma et al., 1999), $5 \mu \mathrm{g}$ of histone $\mathrm{H} 1$, and $5 \mu \mathrm{Ci}$ of $\left[\gamma^{-}{ }^{32} \mathrm{P}\right] \mathrm{ATP}$ at $30^{\circ} \mathrm{C}$ for 20 min, respectively. The flow containing $50 \mu \mathrm{l}$ of phosphorylated substrate solution was analyzed by $12.5 \%$ SDS-PAGE followed by autoradiography. For quantification, protein bands corresponding to histone $\mathrm{H} 1$ were excised, and radioactivity was measured by liquid scintillation counting. To determine Cdk5 kinase activity in vivo, septal and hippocampal lysates were obtained from mice injected with aCSF or butyrolactone I $15 \mathrm{~min}$ before and killed $30 \mathrm{~min}$ after the training. The kinase assay was performed as described above except that $30 \mu \mathrm{g}$ of total lysates was incubated with histone $\mathrm{H} 1$ without previous immunoprecipitation of $\mathrm{Cdk} 5$.

Statisical analysis. Statistical analysis was performed by unpaired Student's $t$ test or one-way ANOVA followed by Scheffé's test for post hoc 
A



Cdk5

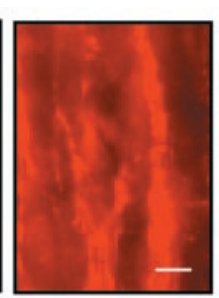

AchE

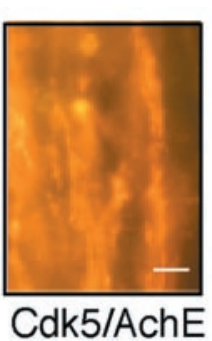

Cdk5/AchE
B

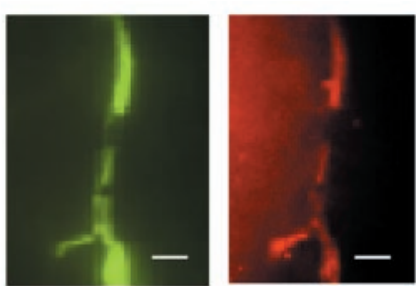

CDK5 Neurofilament 68

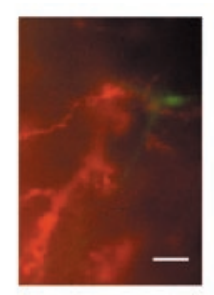

CDK5

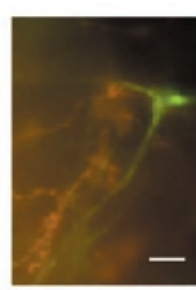

Glial fibrillary acidic protein
C

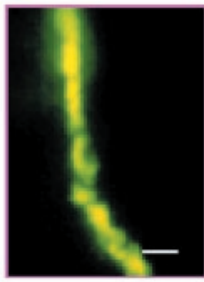

Cdk5

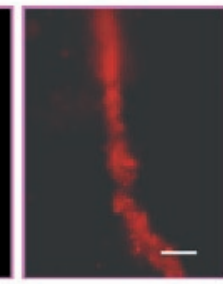

p35

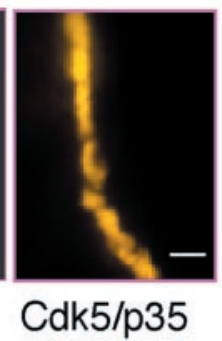

D

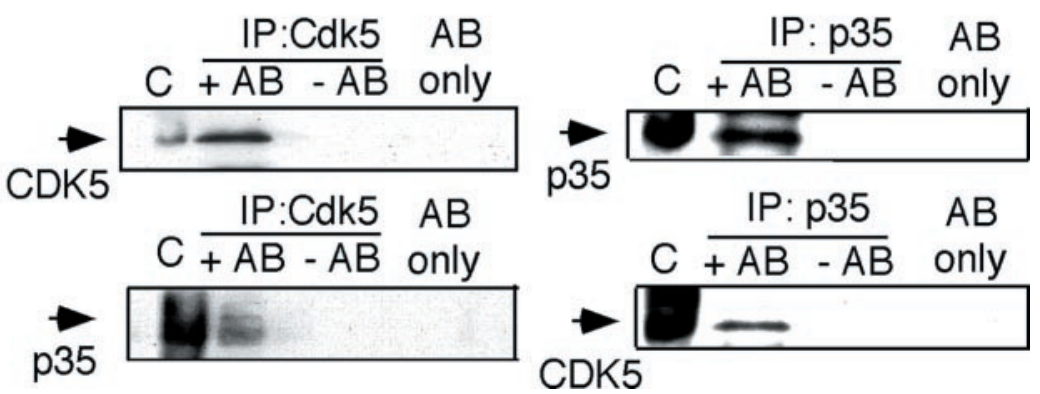

Figure 3. Localization of Cdk5 in cholinergic septohippocampal fibers of mice stressed for $1 \mathrm{hr}$ and killed $0.5 \mathrm{hr}$ later. A, Staining for Cdk5 ( green), acetylcholinesterase (AchE, red), and their coimmunolabeling (yellow) within septohippocampal fibers. Scale bar, $50 \mu \mathrm{m}$. $B$, Double staining of sections with Cdk5 (green) and neurofilament 68 (red) or Cdk5 (red) and glial fibrillary acidic protein (green). Scale bar, $10 \mu \mathrm{m}$. C, Staining of Cdk5 (green), p35 (red), and their coimmunolabeling ( yellow) within septohippocampal fibers. Scale bar, $10 \mu \mathrm{m}$. $D$, Coimmunoprecipitation of Cdk5 with p35. $C$, Crude extract; $I P$, antibody used for immunoprecipitation. Lysates incubated with antibody $(+A B)$, without antibody $(-A B)$, and antibody only $(A B$ only) were analyzed by immunoblot. Arrows indicate the antibody used for immunodetection and the corresponding signal. The data of naive mice are not presented, because Cdk5 protein levels in the septohippocampal system were undetectable (Fig. 2).

comparison where appropriate. The results are presented as mean \pm SEM.

\section{RESULTS}

Cdk5 is differentially expressed in the septohippocampal system of stressed mice

By using subtractive hybridization, we have detected differential expression of 10 gene fragments, including several uncharacterized genes as well as the immediate early genes $c$-fos and zif 268 . One of the cDNA fragments differentially expressed in the septum of stressed mice was identified as Cdk5. Consistently, a transient upregulation of mRNA coding for $\mathrm{Cdk} 5$ was detected by RT-PCR (Fig. 1A-C) and in situ hybridization (Fig. 1D) $30 \mathrm{~min}$ after the end of immobilization. $C d k 5$ gene expression returned to baseline within $1.5 \mathrm{hr}$, followed by a downregulation within 3-24 hr after immobilization (Fig. 1B,C). In agreement with previous studies, immunohistochemical analysis of $\mathrm{Cdk} 5$ production of naive mice revealed its predominant dendritic and axonal distribution (Tsai et al., 1993) in the arcuate hypothalamic nucleus, area postrema, cerebellum (Pigino et al., 1997), and white matter (Tsai et al., 1993), including the fimbria/fornix pathway. The levels of Cdk5 in the neocortex, striatum (data not shown), hippocampus, and septum (Fig. $2 A, B$, naive) were low or undetectable. In response to immobilization, a significant increase of $\mathrm{Cdk} 5$ protein production was detected in the lateral and medial septum, as well as the mediodorsal hippocampus, but not in other forebrain areas (Fig. 2A,B). The observed increases of $C d k 5$ mRNA and protein in response to stress were restricted to the caudal septal region $(+0.6$ to $+0.38 \mathrm{~mm}$ anterior to the bregma) (Franklin and Paxinos, 1997).

\section{Cdk5 activity is increased in septohippocampal cholinergic neurons of stressed mice}

$\mathrm{Cdk} 5$ was upregulated in cholinergic neurons, as demonstrated by the finding that all neurons within the septohippocampal and fimbria-fornix fibers staining for $\mathrm{Cdk} 5$ also contained acetylcholinesterase (Fig. $3 A$ ). Neuronal localization was also confirmed by the finding that $\mathrm{Cdk} 5$ colocalized with neurofilament 68 but not with glial fibrillary acidic protein (Fig. $3 B$ ). Coimmunolabeling of brain tissue with Cdk5 and its activator p35 (Tsai et al., 1994) demonstrated overlapping signals in neuronal fibers (Fig. 3C). This subcellular distribution pattern implied that within the septohippocampal system, neuronal function might be modulated through the cytoplasmic kinase activity of the Cdk5/p35 complex. Consistently, association between $\mathrm{Cdk} 5$ and p35 was demonstrated by coimmunoprecipitation studies (Fig. 3D). Cdk5 immunoprecipitated from septohippocampal lysates of stressed mice exhibited high histone H1 kinase activity that was fully blocked by the Cdk5 inhibitor (Kitagawa et al., 1994) butyrolactone I (see Fig. $5 F)$.

\section{Inhibition of Cdk5 activity in the septum and hippocampus prevents stress-induced facilitation of context-dependent fear conditioning}

Butyrolactone I selectively inhibits the kinase activities of Cdk1, Cdk2, and Cdk5 (Pigino et al., 1997). To determine whether $\mathrm{Cdk} 1$ and $\mathrm{Cdk} 2$ are produced in the septohippocampal system, we performed immunoblot analysis of septohippocampal lysates. Consistently with our previous observations, Cdk5 was upregulated in response to stress; however, we did not observe detectable protein levels of $\mathrm{Cdk} 1$ or $\mathrm{Cdk} 2$ in naive and stressed mice (Fig. $4 A$ ). On this basis, butyrolactone I was used as a selective antag- 
A



C

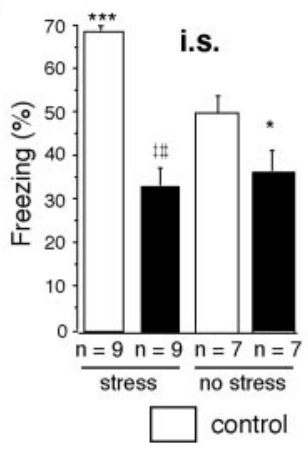

D

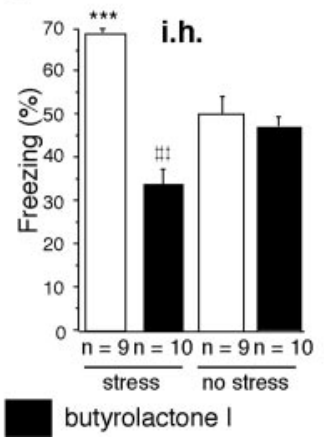

Figure 4. Butyrolactone I prevents stress-induced facilitation of contextdependent fear conditioning. $A$, Immunoblot of septohippocampal lysates (30 $\mu \mathrm{g} /$ lane) stained with antibodies to Cdk1, Cdk2, and Cdk5. Note the positive signal for Cdk5 in mice stressed for $1 \mathrm{hr}$ and killed $0.5 \mathrm{hr}$ later, but not for $\mathrm{Cdk} 1$ or $\mathrm{Cdk} 2$ in naive or identically stressed mice. Positive controls consisted of spleen cell lysate (30 $\mu \mathrm{g} /$ lane) and epidermal growth factor-stimulated A431 cell lysate $(20 \mu \mathrm{g} /$ lane). B, Experimental design. $C$, Effect of butyrolactone I injected into the intermediate septum before stress and fear conditioning on freezing during the context-dependent memory test. Significant group differences $\left(F_{(3,30)}=17.14 ; p<0.001\right)$ were observed. $D$, Effect of butyrolactone injected into the mediodorsal hippocampus before stress and fear conditioning on freezing during the context-dependent memory test. Significant group differences $\left(F_{(3,35)}=\right.$ 8.673; $p<0.001)$ were observed. Post hoc analyses: ${ }^{*} p<0.05$ versus nonstressed vehicle group; ${ }^{* * *} p<0.01$ versus nonstressed vehicle group; $\stackrel{+}{+} p<0.001$, stressed butyrolactone I group versus stressed vehicle group.

onist for Cdk5 within the septohippocampal system. To investigate the role of $\mathrm{Cdk} 5$ in stress-enhanced fear conditioning, we injected butyrolactone I or vehicle into the lateral intermediate septum or mediodorsal hippocampus of cannulated mice $15 \mathrm{~min}$ before their immobilization (Fig. 4B). After $3 \mathrm{hr}$, the mice were trained in a context-dependent fear-conditioning paradigm consisting of a single pairing of context and foot shock. The memory test was performed $24 \mathrm{hr}$ later by re-exposing the mice to the conditioning context and measuring their freezing response as an index of acquired fear. Additional control groups were treated identically, except that the stress was omitted. In agreement with our previous findings (Radulovic et al., 1999), mice pre-exposed to immobilization froze significantly more than nonstressed mice (Fig. $4 C, D$ ). Injection of butyrolactone I into the intermediate septum (Fig. $4 C$ ) or mediodorsal hippocampus (Fig. 4D) before immobilization fully prevented stress-induced facilitation of context-dependent conditioning. Thus, we could demonstrate the involvement of Cdk5 in stress-enhanced memory consolidation. Importantly, nonstressed mice injected in the intermediate septum with butyrolactone I froze significantly less than mice injected in the intermediate septum with vehicle (Fig. $4 C$ ). This finding suggested that $\mathrm{Cdk} 5$ was also involved in associative learning of nonstressed mice.

\section{Cdk5 production and activity is required for context-dependent fear conditioning}

To determine whether transient activation of $\mathrm{Cdk} 5$ plays a role in the acquisition of conditioned fear, we measured the production of Cdk5 in the septohippocampal system at different time points after context-dependent fear conditioning. Control groups consisted of naive mice, mice exposed to the context without foot shock, and mice exposed to an immediate foot shock followed by context. The latter training conditions do not result in associative learning and were therefore used to delineate the impact of associative learning on Cdk5 production from the effects of nonassociative learning and unconditioned stress responses to foot shock (Atkins et al., 1998; Milanovic et al., 1998). Unlike immobilization (Fig. $2 A, B$ ), the novel context or immediate foot shock (Fig. $5 A-D$ ) did not upregulate $\mathrm{Cdk} 5$, indicating that $\mathrm{Cdk} 5$ production depended on the type of stressor. Importantly, exposure of mice to a paired presentation of context and shock induced a transient increase of $\mathrm{Cdk} 5$ protein levels in the septum (Fig. $5 A, B$ ) and hippocampus (Fig. $5 C, D$ ) following a time course similar to the one described after immobilization (Fig. 2). Absence of $\mathrm{Cdk} 5$ changes in the control groups indicated that under these conditions, the observed effect was specific for associative learning. Moreover, the $\mathrm{Cdk} 5$ kinase activity was significantly increased in septohippocampal neurons after fear conditioning, although not to the same extent as in response to immobilization (Fig. 5E, F). The 10 -fold increase of Cdk5 protein levels may seem inconsistent with the $25 \%$ increase of Cdk5 activity of the context-shock group. Note, however, that the immunohistochemical quantification was performed in defined sections of the lateral septum and hippocampus, whereas kinase activity was determined in total septohippocampal lysates containing Cdk5positive as well as -negative areas. Furthermore, fourfold to fivefold increases of the levels of p35 were also observed $30 \mathrm{~min}$ after exposure to context-shock $(p<0.05)$ or immobilization $(p<0.05)$ (Fig. $5 F)$, indicating that this $\mathrm{Cdk} 5$ activator could also contribute to the increase of $\mathrm{Cdk} 5$ kinase activity. Injection of butyrolactone I into the intermediate septum and mediodorsal hippocampus $15 \mathrm{~min}$ before training (Fig. $6 \mathrm{~A}$ ) significantly reduced the $\mathrm{Cdk} 5$ kinase activity in vivo $30 \mathrm{~min}$ after the training and impaired acquisition of conditioned fear (Fig. 6B). These treatments did not affect the exploratory behavior, locomotor activity, and burst to foot shock (data not shown). Furthermore, the same dose of butyrolactone I into the lateral brain ventricles (intracerebroventricular injection) was less effective than the described regional applications (Fig. 6B). Injections into neighboring regions such as the striatum did not exhibit any detectable effect (data not shown), further supporting the specific role of septohippocampal Cdk5 in memory consolidation. The described treatments did not affect tone-dependent fear conditioning (Fig. $6 C, D)$, indicating a selective role of $\mathrm{Cdk} 5$ in contextual fear conditioning. Notably, the septum (Sparks and LeDoux, 1995) and hippocampus (Kim and Fanselow, 1992) are not required for tone-dependent fear conditioning. Contextual fear conditioning was significantly impaired by injection of butyrolactone I into the intermediate septum or mediodorsal hippocampus immediately after the training (Fig. $6 F, G$ ). However, injections performed $3 \mathrm{hr}$ after the training did not affect contextual fear conditioning (Fig. $6 F, G)$. The findings that $\mathrm{Cdk} 5$ production and the in vivo effect of butyrolactone I lasted $<3 \mathrm{hr}$ demonstrated that $\mathrm{Cdk} 5$ plays a role 
A



C

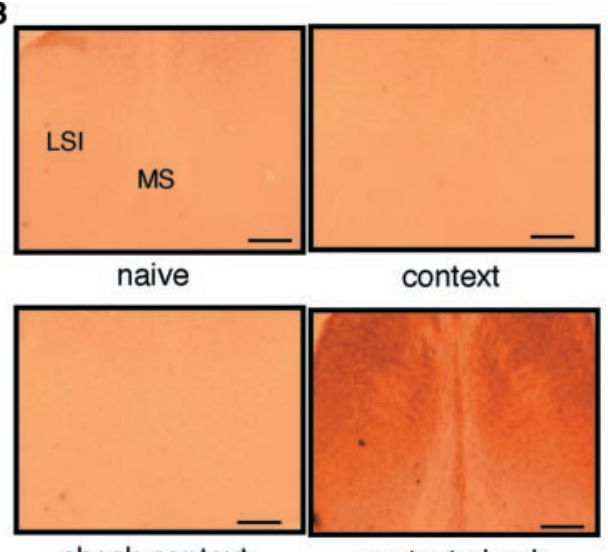

context-shock

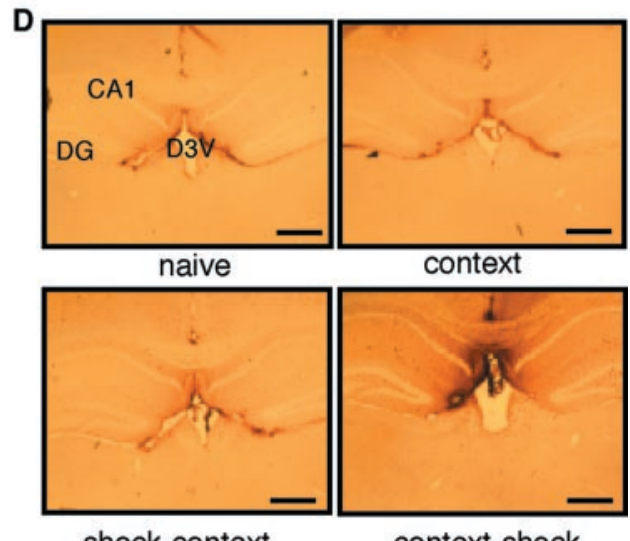

context-shock

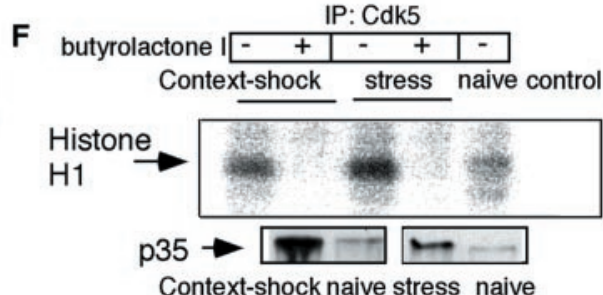

Figure 5. Context-dependent fear conditioning results in increased level and activity of septohippocampal Cdk5. $A$, Increased Cdk5 levels in the septum 30 min after fear conditioning. Mean density of three mice per group and representative photomicrograph $(B)$. Scale bar, $200 \mu \mathrm{m}$. $C$, Increased Cdk5 levels in the hippocampus $30 \mathrm{~min}$ after fear conditioning. Mean density of three mice per group and representative photomicrograph $(D)$. Scale bar, $400 \mu \mathrm{m}$. E, Comparison of histone H1 phosphorylation of Cdk5 immunoprecipitated 30 min after fear conditioning or immobilization. Septohippocampal lysates were tested in the presence or absence of butyrolactone I. $F$, Representative autoradiogram from the experiment described in $E$ (above). Control indicates a sample with radioactivity only (without an immunoprecipitated lysate). Bottom panels, Representative immunoblot indicating p35 levels in the septohippocampal lysates used above to determine $\mathrm{Cdk} 5$ kinase activity. $C A 1$, Hippocampal subfield; $D 3 V$, dorsal third ventricle; $D G$, dentate gyrus; $L S I$, lateral intermediate septum; $M S$, medial septum. ${ }^{* *} p<0.01$ versus naive; $* * * p<0.0001$ versus naive; $\mathbb{T} p<$ 0.0001 versus corresponding group with butyrolactone I $(10 \mu \mathrm{M})$. in the consolidation of contextual memory within a restricted time window after the training.

\section{DISCUSSION}

Here, we show a novel pattern of $C d k 5$ regulation by demonstrating the transient increase of $C d k 5$ expression and function in response to environmental stimuli leading to the formation of associative learning or its facilitation. This finding was unexpected, in view of previous observations reporting Cdk5 upregulation in the adult CNS only after long-term manipulations, such as chronic electroconvulsive stimulation (Chen et al., 2000), $\Delta$ FosB overexpression (Bibb et al., 2001), cocaine (Bibb et al., 2001) treatment, or apoptosis (Neystat et al., 2001). The finding that the time course of $\mathrm{Cdk} 5$ upregulation was similar to the one of inducible immediate early genes (Cole et al., 1989; Radulovic et al., 1998b) was also surprising, considering that the activity of other kinases involved in learning is regulated primarily by phosphorylation (Roberson and Sweatt, 2001). However, the recently observed upregulation of the KKIAMRE kinase during associative learning (Gomi et al., 1999) is consistent with our results and may suggest a regulatory pattern typical for neuronal cdc2-related kinases.

Thus far, the role of protein kinases in memory consolidation has been ascribed primarily to their direct regulation of transcription (Silva et al., 1997; Abel et al., 1998; Roberson and Sweatt, 2001). Absence of Cdk5 in the nucleus and its cytoplasmic colocalization with neurofilament 68 suggest that Cdk5 affects learning through different mechanisms. The physiological activity of Cdk5 in the brain has been linked primarily to cytoskeletal phosphorylation, leading to neuronal migration (Ohshima et al., 1996; Chae et al., 1997), axon growth (Nikolic et al., 1998; Smith et al., 2001), and possibly neurosecretion (Matsubara et al., 1996; Fletcher et al., 1999). Notably, the demonstrated effects of Cdk5 in associative learning could involve processes similar to those described during development. Cdk5 activity significantly affects the cytoskeletal dynamics that were recently linked to morphological changes leading to long-term plasticity (Hatada et al., 2000). Moreover, modulation of the cytoskeleton affects the anchoring and function of nicotinic and muscarinic cholinergic 
A

\section{B contextual fear conditioning}
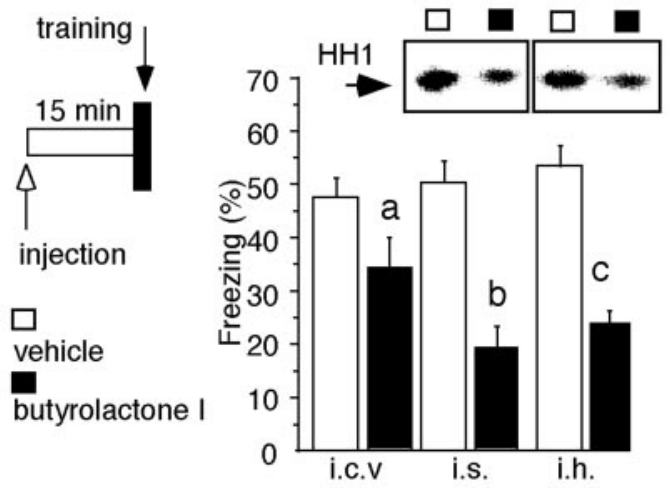

C tone-dependent fear conditioning



D tone-dependent fear conditioning ${ }^{70}$ i.h.


Figure 6. Effect of butyrolactone I on context- and tone-dependent fear conditioning. $A$, Experimental design of pretraining injections. $B$, Effect of butyrolactone I injected intracerebroventricularly (i.c.v.), into the intermediate septum (i.s.), or into the mediodorsal hippocampus (i.h.) before training on freezing during the context-dependent memory test. Statistically significant differences were observed after injections given intracerebroventricularly $\left(t_{(1,23)}=2.538\right)$, into the intermediate septum $\left(t_{(1,12)}=3.888\right)$, and into the mediodorsal hippocampus $\left(t_{(1,15)}=3.403\right)$. Group comparisons: ${ }^{\mathrm{a}} p<0.05$ versus vehicle administered intracerebroventricularly; ${ }^{\mathrm{b}} p<0.01$ versus vehicle administered to the intermediate septum; ${ }^{c} p<0.001$ versus vehicle administered to the mediodorsal hippocampus. Autoradiograms above the bars obtained from mice injected into the intermediate septum or mediodorsal hippocampus indicate decreased phosphorylation of histone $\mathrm{H} 1$ (HH1) within the septum and hippocampus of mice injected with butyrolactone $\mathrm{I}$ in these areas. $C$, Effect of butyrolactone I injected into the intermediate septum (i.s.) before training on freezing in a novel context and during the tone- receptors (Bencherif and Lukas, 1993), suggesting a functional link between $\mathrm{Cdk} 5$ and the septohippocampal cholinergic system in processes underlying memory consolidation. In addition, the recently demonstrated role of $\mathrm{Cdk} 5$ in the regulation of hippocampal NMDA receptor function may also provide a molecular basis for the observed effects of Cdk5 in associative learning (Li et al., 2001).

Increasing evidence suggests that $\mathrm{Cdk} 5$ hyperactivity may be involved in the pathogenesis of neurodegenerative diseases, such as Alzheimer's disease (Patrick and Zukerberg, 1999; Alvarez et al., 2001), characterized by hyperphosphorylation of the cytoskeleton and decreased cholinergic transmission (Morrison and Hof, 1997), leading to dementia. In this respect, failure to regulate $\mathrm{Cdk} 5$ activity within the septohippocampal cholinergic system may contribute to the pathophysiological hyperactivity of Cdk5. However, on the basis of the presented data, it may be considered alternatively that the increased activity of $\mathrm{Cdk} 5$ in the brain of Alzheimer's patients and experimental models of neurodegeneration may represent a compensatory mechanism to overcome the learning deficits.

In conclusion, tightly regulated $\mathrm{Cdk} 5$ activity, demonstrated by its short-term transient upregulation, is required for memory consolidation during associative learning. Characterization of the upstream induction and downstream targets of $\mathrm{Cdk} 5$ within the septohippocampal cholinergic system will facilitate the delineation of the mechanisms involving $\mathrm{Cdk} 5$ actions in memory consolidation from those related to neurodegeneration.

\section{REFERENCES}

Abel T, Martin KC, Bartsch D, Kandel E (1998) Memory suppressor genes: inhibitory constraints on the storage of long-term memory. Science 279:338-341.

Alvarez A, Munoz JP, Maccioni RB (2001) A cdk5-p35 stable complex is involved in the beta-amyloid-induced deregulation of cdk 5 activity in hippocampal neurons. Exp Cell Res 264:266-274.

Atkins CM, Selcher JC, Petraitis JJ, Trzaskos JM, Sweatt JD (1998) The MAPK cascade is required for mammalian associative learning. Nat Neurosci 7:602-609.

Bencherif M, Lukas RJ (1993) Cytochalasin modulation of nicotinic cholinergic receptor expression and muscarinic receptor function in human TE671/RD cells: a possible functional role of the cytoskeleton. J Neurochem 61:852-864.

Bibb JA, Chen J, Taylor JR, Svenningsson P, Nishi A, Snyder GL, Yan Z, Sagawa ZK, Ouimet CC, Nairn AC, Nestler EJ, Greengard P (2001) Effects of chronic exposure to cocaine are regulated by the neuronal protein Cdk5. Nature 410:376-380.

Cammarota M, Bevilaqua LR, Ardenghi P, Paratcha G, Levi de Stein M, Izquierdo I, Medina JH (2000) Learning-associated activation of nuclear MAPK, CREB and Elk-1, along with Fos production, in the rat

dependent memory test. The treatment did not affect freezing in a novel context $\left(t_{(1,31)}=1.003 ; p=0.337\right)$ or the tone $\left(t_{(1,31)}=0.529 ; p=0.4809\right)$. $D$, Effect of butyrolactone I injected into the mediodorsal hippocampus (i.h.) before training on freezing in a novel context and during the tone-dependent memory test. The treatment did not affect freezing in a novel context $\left(t_{(1,23)}=0.553 ; p=0.4645\right)$ or the tone $\left(t_{(1,23)}=1.74 ; p=\right.$ 0.2001). E, Experimental design of post-training injections. $F$, Effect of butyrolactone I injected into the intermediate septum (i.s.) immediately or $3 \mathrm{hr}$ after the training on freezing during the context-dependent memory test. Butyrolactone I injected into the intermediate septum impaired fear conditioning $\left(t_{(1,11)}=3.182\right)$ when applied immediately but not $3 \mathrm{hr}$ after the training $\left(t_{(1,12)}=0.027\right)$. Group comparisons: ${ }^{\mathrm{a}} p<0.01$ versus vehicle administered into the intermediate septum. $G$, Effect of butyrolactone I injected into the mediodorsal hippocampus (i.h.) immediately or $3 \mathrm{hr}$ after the training on freezing during the context-dependent memory test. Butyrolactone I injected into the mediodorsal hippocampus impaired fear conditioning $\left(t_{(1,14)}=5.958\right)$ when applied immediately but not $3 \mathrm{hr}$ after the training $\left(t_{(1,14)}=0.033\right)$. Group comparisons: ${ }^{\mathrm{a}} p<0.01$ versus vehicle administered into the intermediate septum. 
hippocampus after a one-trial avoidance learning: abolition by NMDA receptor blockade. Brain Res Mol Brain Res 76:36-46.

Chae T, Kwon YT, Bronson R, Dikkes P, Li E, Tsai LH (1997) Mice lacking $\mathrm{p} 35$, a neuronal specific activator of $\mathrm{Cdk} 5$, display cortical lamination defects, seizures, and adult lethality. Neuron 18:29-42.

Chen J, Zhang Y, Kelz MB, Steffen C, Ang ES, Zeng L, Nestler EJ (2000) Induction of cyclin-dependent kinase 5 in the hippocampus by chronic electroconvulsive seizures: role of $\Delta$ FosB. J Neurosci 24:8965-8971.

Cole AJ, Seffen DW, Baraban JM, Worley PF (1989) Rapid increase of an immediate early gene messenger-RNA in hippocampal-neurons by synaptic NMDA receptor activation. Nature 340:474-476.

Fletcher AI, Shuang R, Giovannucci DR, Zhang L, Bittner MA, Stuenkel EL (1999) Regulation of exocytosis by cyclin-dependent kinase 5 via phosphorylation of Munc 18. J Biol Chem 274:4027-4035.

Franklin KBJ, Paxinos G (1997) The mouse brain in stereotaxic coordinates. San Diego: Academic.

Gomi H, Sun W, Finch CE, Itohara S, Yoshimi K, Thompson RF (1999) Learning induces a CDC2-related protein kinase, KKIAMRE. J Neurosci 21:9530-9537.

Hatada Y, Wu F, Sun ZY, Schacher S, Goldberg DJ (2000) Presynaptic morphological changes associated with long-term synaptic facilitation are triggered by actin polymerization at preexisting varicositis. J Neurosci 20:RC82:1-5.

Kim JJ, Fanselow MS (1992) Modality-specific retrograde-amnesia of fear. Science 256:675-677.

Kishimoto T, Radulovic J, Radulovic M, Lin CR, Schrick C, Hooshmand F, Hermanson O, Rosenfeld MG, Spiess J (2000) Gene deletion reveals an anxiolytic role for corticotropin-releasing factor receptor 2 . Nat Genet 24:415-419.

Kitagawa M, Higashi H, Takahashi IS, Okabe T, Ogino H, Taya Y, Hishimura S, Okuyama A (1994) A cyclin-dependent kinase inhibitor, butyrolactone-I, inhibits phosphorylation of $\mathrm{Rb}$ protein and cell cycle progression. Oncogene 9:2549-2557.

Li BS, Sun MK, Zhang L, Takahashi S, Ma W, Vinade L, Kulkarni AB, Brady RO, Pant HC (2001) Regulation of NMDA receptors by cyclindependent kinase-5. Proc Natl Acad Sci USA 98:12742-12747.

Maren S, Fanselow MS (1997) Electrolytic lesions of the fimbria/fornix, dorsal hippocampus, or entorhinal cortex produce anterograde deficits in contextual fear conditioning in rats. Neurobiol Learn Mem 67:142-149.

Mark GP, Rada PV, Shors TJ (1996) Inescapable stress enhances extracellular acetylcholine in the rat hippocampus and prefrontal cortex but not the nucleus accumbens or amygdala. Neuroscience 74:767-774.

Matsubara M, Kusubata M, Ishiguro K, Uchida T, Titani K, Taniguchi H (1996) Site-specific phosphorylation of synapsin I by mitogen-activated protein kinase and $\mathrm{Cdk} 5$ and its effects on physiological functions. J Biol Chem 271:21108-21113.

Milanovic S, Radulovic J, Laban O, Stiedl O, Spiess J (1998) Production of the Fos protein after contextual fear conditioning of C57BL/6N mice. Brain Res 784:37-47.

Morrison JH, Hof P (1997) Life and death of neurons in the aging brain. Science 278:412-419.
Neystat M, Rzhetskaya M, Oo TF, Kholodilov N, Yarygina O, Wilson A, El-Khodor BF, Burke RE (2001) Expression of cyclin-dependent kinase 5 and its activator p35 in models of induced apoptotic death in neurons of the substantia nigra in vivo. J Neurochem 77:1611-1625.

Nikolic M, Chou MM, Lu W, Mayer BJ, Tsai LH (1998) The p35/Cdk5 kinase is a neuron-specific Rac effector that inhibits Pak1 activity. Nature 359:194-198.

Ohshima T, Ward JM, Huh CG, Longenecker G, Veeranna, Pant HC, Brady RO, Martin LJ, Kulkarni AB (1996) Targeted disruption of the cyclin-dependent kinase 5 gene results in abnormal corticogenesis, neuronal pathology and perinatal death. Proc Natl Acad Sci USA 93:11173-11178.

Patrick GN, Zukerberg L, Nikolic M, de la Monte S, Dikkes P, Tsai LH (1999) Conversion of p35 to p 25 deregulates Cdk5 activity and promotes neurodegeneration. Nature 402:615-622.

Pigino G, Paglini G, Ulloa L, Avila J, Caceres A (1997) Analysis of the expression, distribution and function of cyclin dependent kinase 5 (cdk5) in developing cerebellar macroneurons. J Cell Sci 110:257-270.

Radulovic J, Sydow S, Spiess J (1998a) Characterization of native corticotropin-releasing factor receptor type 1 (CRFR1) in the rat and mouse central nervous system. J Neurosci Res 54:507-521.

Radulovic J, Kammermeier J, Spiess J (1998b) Relationship between FOS production and classical fear conditioning: effects of novelty, latent inhibition, and unconditioned stimulus preexposure. J Neurosci 18:7452-7461.

Radulovic J, Rühmann A, Liepold T, Spiess J (1999) Modulation of learning and anxiety by corticotropin-releasing factor (CRF) and stress: differential roles of CRF receptors 1 and 2. J Neurosci 12:5016-5025.

Roberson ED, Sweatt JD (2001) Memory-forming chemical reactions. Rev Neuroscience 12:41-50.

Serova LI, Saez E, Speigelman BM, Sabban EL (1998) c-Fos deficiency inhibits induction of mRNA for some, but not all, neurotransmitter biosynthetic enzymes by immobilization stress. J Neurochem 70:1935-1940.

Sharma P, Sharma M, Amin ND, Albers RW, Pant HC (1999) Regulation of cyclin-dependent kinase 5 catalytic activity by phosphorylation. Proc Natl Acad Sci USA 96:11156-11160.

Shors TJ, Weiss C, Thompson RF (1992) Stress-induced facilitation of classical conditioning. Science 24:537-539.

Silva AJ, Smith AM, Giese KP (1997) Gene targeting and the biology of learning and memory. Annu Rev Genet 31:527-546.

Smith S, Greer PL, Tsai L-H (2001) Cdk5 on the brain. Cell Growth Differ 12:277-283.

Sparks PD, LeDoux JE (1995) Septal lesions potentiate freezing behavior to contextual but not to phasic conditioned stimuli in rats. Behav Neurosci 109:184-188.

Tsai L-H, Takahashi T, Caviness Jr VS, Harlow E (1993) Activity and expression pattern of cyclin-dependent kinase 5 in the embryonic mouse nervous system. Development 119:1029-1040.

Tsai LH, Delalle I, Caviness VS, Chae T, Harlow E (1994) P35 is a neural-specific regulatory subunit of cyclin-dependent kinase 5 . Nature $371: 419-423$ 